\title{
PENETAPAN KADAR AMILOSA DAN PROTEIN PADA BERAS SOLOK JENIS ANAK DARO DAN SOKAN YANG DITANAM DENGAN SISTEM PERTANIAN ORGANIK DAN SISTEM PERTANIAN KONVENSIONAL
}

\author{
Rini Lestari ${ }^{1)}$ Sri Kartini ${ }^{1)}$ Lusiana Berti ${ }^{1)}$ Megi Romita ${ }^{1)}$ \\ ${ }^{1)}$ D III Analis Farmasi dan Makanan, FKIK Universitas Abdurrab \\ Jl. Riau Ujung No 73 Pekanbaru, Indonesia \\ Korespondensi penulis : rini.lestari@univrab.ac.id
}

\begin{abstract}
The organic farming system is a holistic agricultural production management system for improving and developing agro-ecosystem health, including biodiversity, biological cycles, and soil biological activities. Organic farming systems use natural fertilizers and pesticides, while conventional farming systems still use chemical fertilizers and pesticides. Environmental conditions are expected to affect the chemical content of rice. One of the main chemical constituents in rice is amylose and protein. This research is a laboratory experimental study that aims to see the amylose and protein content of Solok rice types sokan and anak daro which grown with organic farming system and conventional farming system. From the result of the research, equation of calibration curve amylose is $Y=0,0246 X+0,0146$ with correlation coefficient $(r)=0,9984$. Amylose content of Solok rice type of anak daro organic 28,90\%, anak daro conventional 28,04\%, sokan organic 30,32\% and sokan conventional 30,94\%. Protein content of Solok rice type of anak daro organic 8,79\%, anak daro conventional $8,15 \%$, sokan organic $8,50 \%$ and sokan conventional $8,25 \%$. T value of each group is smaller than the $T$ table value, it can be concluded that the result is not significantly different.
\end{abstract}

Keywords : amylose, protein, anak daro rice, sokan rice, organic

\section{ABSTRAK}

Sistem pertanian organik adalah sistem manajemen produksi pertanian yang holistik untuk meningkatkan dan mengembangkan kesehatan agro-ekosistem, termasuk keragaman hayati, siklus biologi, dan aktivitas biologi tanah. Sistem pertanian organik menggunakan pupuk dan pestidida alami, sedangkan sistem pertanian konvensional masih menggunakan pupuk dan pestisida kimia. Kondisi lingkungan diperkirakan akan mempengaruhi kandungan kimia pada beras. Salah satu kandungan kimia utama pada beras adalah amilosa dan protein. Penelitian ini merupakan penelitian eksperimental laboratorium yang bertujuan untuk melihat kandungan amilosa dan protein pada beras Solok jenis sokan dan anak daro yang ditanam dengan sistem pertanian organik dan sistem pertanian konvensional. Dari pelaksanaan penelitian didapatkan hasil persamaan kurva kalibrasi pembanding amilosa $\mathrm{Y}=0,0246 \mathrm{X}+0,0146$ dengan nilai koefisien korelasi $(\mathrm{r})=0,9984$. Kadar amilosa beras Solok jenis anak daro organik 28,90\%, anak daro konvensional 28,04\%, sokan organik 30,32\% dan sokan konvensional 30,94\%. Kadar protein beras Solok jenis anak daro organik 8,79\%, anak daro konvensional 8,15\%, sokan organik 8,50\%, dan sokan konvensional 8,25\%. Nilai T hitung dari masing-masing kelompok lebih kecil daripada nilai $\mathrm{T}$ tabel, dapat disimpulkan bahwa hasilnya tidak berbeda nyata.

Kata kunci : amilosa, protein, beras anak daro, beras sokan, organik 


\section{Pendahuluan}

Pangan organik adalah pangan yang berasal dari suatu lahan pertanian organik yang menerapkan praktek pengelolaan yang bertujuan untuk memelihara ekosistem dalam mencapai produktivitas yang berkelanjutan, melakukan pengendalian gulma, hama, dan penyakit, melalui beberapa cara seperti daur ulang sisa tumbuhan dan ternak, seleksi dan pergiliran tanaman, pengelolaan air, pengolahan lahan, dan penanaman serta penggunaan bahan hayati. Sistem pertanian organik adalah sistem manajemen produksi pertanian yang holistik untuk meningkatkan dan mengembangkan kesehatan agro-ekosistem, termasuk keragaman hayati, siklus biologi, dan aktivitas biologi tanah [1].

Konsumsi makanan organik salah satunya beras organik menjadi trend dalam beberapa tahun terakhir. Alasannya beras organik memiliki kualitas rasa yang enak dan juga menyehatkan. Beras organik diyakini baik dikonsumsi oleh penderita diabetes karena diyakini memiliki indeks glikemik yang rendah. Beras organik adalah beras yang dihasilkan dari sistem pertanian organik [2].

Produksi beras organik sangat bermanfaat bagi kelangsungan ekosistem, selain itu juga diharapkan beras organik memiliki kandungan kimia yang lebih baik dibandingkan dengan beras yang ditanam secara konvensional. Proses produksi dan kondisi lingkungan diperkirakan akan mempengaruhi kandungan kimia pada tanaman. Salah satu kandungan kimia utama pada beras adalah amilosa dan protein. Penelitian ini bertujuan untuk melihat kandungan amilosa dan protein pada beras Solok jenisanak daro dan sokan yang ditanam dengan sistem pertanian organik dan sistem pertanian konvensional.

\section{Tinjauan Pustaka}

Tujuan utama dari sistem pertanian organik adalah memperbaiki dan menyuburkan kondisi lahan serta menjaga keseimbangan ekosistem. Budidaya tanaman padi secara organik memeberikan beberapa keuntungan, diantaranya mengembalikan kesuburan tanah, menjanjikan keuntungan yang lebih besar karena harga jual beras organik lebih tinggi, dan secara medis menyehatkan masyarakat [2][3]

Manfaat dari sistem pertanian organik antara lain [3]:

1. Meningkatkan pendapatan petani karena adanya efisiensi manfaat sumber daya.

2. Menciptakan lingkungan kerja yang aman dan sehat.

3. Meminimalkan semua bentuk polusi yang dihasilkan dari kegiatan pertanian.

4. Meningkatkan dan menjaga produktivitas lahan pertanian dalam jangka panjang serta memelihara kelestarian sumber daya alam dan lingkungan.

5. Menciptakan lapangan kerja baru dan keharmonisan sosial di pedesaan.

6. Menghasilkan produk pangan yang cukup aman dan berkualitas sehingga meningkatkan kesehatan masyarakat dan sekaligus daya saing produk agribisnis.

Beras mengandung pati (sekitar 80-85\%), protein, vitamin, mineral, lemak, dan air. Pati beras tersusun dari dua polimer karbohidrat yaitu amilosa (pati dengan struktur unit-unit glukosa berantai lurus dengan ikatan 1,4-D-glukopiranosida) dan amilopektin (pati dengan struktur unit-unit glukosa yang bercabang dengan ikatan 1,6-D- glukopiranosida). Perbandingan komposisi amilosa dan amilopektin sangat menentukan warna (transparan atau tidak) dan tekstur nasi (lengket atau pera). Beras dengan kandungan amilosa yang lebih tinggi membuat tekstur nasi menjadi pera, tidak lengket, dapat mengembang, dan menjadi keras setelah dingin. Beras dengan kadar amilopektin yang tinggi menghasilkan tekstur nasi yang lengket, tidak mengembang, dan tetap menggumpal setelah dingin. Berdasarkan kadar amilosa beras digolongkan menjadi tiga yaitu beras dengan kadar amilosa rendah (10-20\%), menengah (21-25\%), dan tinggi $(26-33 \%)$ [4][5].

Penetapan kadar amilosa dapat dilakukan menggunakan metode spektrofotometri. Panjang gelombang amilosa adalah $620 \mathrm{~nm}$. Kadar amilosa dalam sampel dihitung menggunakan kurva standar amilosa [4][6][7]. Penetapan kadar protein dilakukan dengan metode kjeidahl. Sampel didestruksi terlebih dahulu dengan $\mathrm{H}_{2} \mathrm{SO}_{4}$ pekat, kemudian didestilasi. Destilat dititrasi dengan $\mathrm{HCl} \mathrm{0,02} \mathrm{N}$. Larutan blanko dianalisis seperti sampel. Dengan nilai $\mathrm{T}$ adalah titrasi sampel dengan $\mathrm{HCl}$ dan $\mathrm{B}$ adalah titrasi blanko, maka kadar protein dihitung berdasarkan rumus berikut [8] :

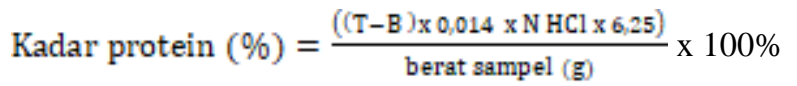




\section{Metode Penelitian}

\subsection{Waktu dan Tempat Penelitian}

Penelitian ini dilakukan selama 7 bulan di laboratorium Prodi D III Analis Farmasi dan Makanan Universitas Abdurrab dan laboratorium Balai Riset dan Standardisasi Industri Pekanbaru.

\subsection{Alat dan Bahan}

Alat yang digunakan pada penelitian ini antara lain blender, ayakan, labu ukur, labu kjeidahl, beaker glass, erlenmeyer, pipet volum, buret, spektrofotometer UV-Vis T 60, timbangan analitik, waterbath.

Bahan yang digunakan pada penelitian ini antara lain beras organik jenis anak daro dan sokan, beras konvensional jenis anak daro dan sokan, akuades, baku pembanding potato amylosa $\left(\mathrm{Merck}^{\circledR}\right), \mathrm{CH}_{3} \mathrm{COOH}$, $\mathrm{HCl}, \mathrm{NaOH}, \mathrm{H}_{2} \mathrm{SO}_{4}, \mathrm{I}_{2}, \mathrm{KI}, \mathrm{K}_{2} \mathrm{SO}_{4}, \mathrm{HgO}, \mathrm{H}_{3} \mathrm{BO}_{3}\left(\right.$ Merck $\left.^{\circledR}\right)$.

\subsection{Pembuatan Larutan Standar Amilosa 1000 mg/L}

Larutan standar amilosa dibuat dengan menimbang $100 \mathrm{mg}$ potato amylosa, ditambahkan $1 \mathrm{~mL}$ alkohol 96\% dan $9 \mathrm{~mL} \mathrm{NaOH} 1 \mathrm{~N}$. Larutan dipanaskan selama 10 menit, kemudian didinginkan 1 jam dan diencerkan dengan akuades sampai volume $100 \mathrm{~mL}$.

\subsection{Penentuan Panjang Gelombang Maksimum dan Waktu Operasional Amilosa}

Larutan standar amilosa $1000 \mathrm{mg} / \mathrm{L}$ dipipet sebanyak $1 \mathrm{~mL}$ ditambahkan $2 \mathrm{~mL} \mathrm{I} 2 \%$ dan asam asetat 0,5 $\mathrm{N} 2 \mathrm{~mL}$ larutan diencerkan dengan akuades sampai volume $100 \mathrm{~mL}$ lalu dibiarkan selama 5 menit. Diukur pada panjang gelombang 400-800 nm, hingga didapatkan data panjang gelombang maksimum amilosa. Larutan diukur pada panjang gelombang maksimum pada menit ke 10, 15, 20, 25, 30, 35, dan 40 .

\subsection{Pembuatan Kurva Kalibrasi Standar Amilosa}

Larutan standar amilosa $1000 \mathrm{mg} / \mathrm{L}$ dipipet masing-masing 0,$25 ; 0,5 ; 0,75 ; 1,0 ; 1,25 ; 1,5 ; 1,75$; dan $2,0 \mathrm{~mL}$ dimasukkan ke dalam labu ukur $100 \mathrm{~mL}$. Pada larutan tersebut ditambahkan $2 \mathrm{~mL} \mathrm{I}_{2} 2 \%$ dan asam asetat $0,5 \mathrm{~N}$ masing-masing 0,$5 ; 1,0 ; 1,5 ; 2,0 ; 2,5 ; 3,0$; dan $4 \mathrm{~mL}$ larutan diencerkan dengan akuades sampai volume $100 \mathrm{~mL}$ hingga didapatkan larutan dengan konsentrasi 2,5; 5,0; 7,5; 10,0; 12,5; 15,0; dan 20,0 mg/L, larutan dikocok kemudian didiamkan selama 20 menit (waktu operasional amilosa), kemudian absorbansinya diukur pada panjang gelombang maksimum amilosa [6].

\subsection{Penetapan Kadar Amilosa Pada Beras}

Penetapan kadar amilosa dilakukan menggunakan metode spektrofotometri. Beras dihaluskan menjadi tepung, kemudian ditimbang sebanyak $100 \mathrm{mg}$ dimasukkan ke dalam erlenmeyer dan ditambahkan $1 \mathrm{~mL}$ alkohol $96 \%$ dan $9 \mathrm{~mL} \mathrm{NaOH} 1 \mathrm{~N}$, kemudian larutan dipanaskan pada suhu $100^{\circ} \mathrm{C}$ selama 10 menit, larutan dimasukkan kedalam labu ukur $100 \mathrm{~mL}$ diencerkan dengan akuades hingga tanda batas. Larutan dipipet $5 \mathrm{~mL}$ dimasukkan ke dalam labu ukur $100 \mathrm{~mL}$ ditambahkan $2 \mathrm{~mL} \mathrm{I} 2 \%$ dan $1 \mathrm{~mL}$ asam asetat 0,5 N. Larutan diencerkan dengan akuades sampai volume $100 \mathrm{~mL}$ larutan dikocok dan didiamkan selama 20 menit (waktu operasional amilosa), sehingga larutan berubah warna menjadi biru mantap. Selanjutnya diukur absorbansinya pada panjang gelombang maksimum dan waktu operasional amilosa. Blanko yang digunakan yaitu akuades yang ditambahkan $\mathrm{I}_{2} 2 \%[6]$.

\subsection{Penetapan Kadar Protein Pada Sampel}

Sampel ditimbang sebanyak 0,5 gram kemudian dimasukkan ke dalam labu kjeidahl $100 \mathrm{~mL}$ lalu ditambahkan 2 gram $\mathrm{K}_{2} \mathrm{SO}_{4}, 40 \mathrm{mg} \mathrm{HgO}$ dan $25 \mathrm{~mL} \quad \mathrm{H}_{2} \mathrm{SO}_{4}$ pekat. Setelah itu didestruksi dengan dipanaskan di atas pemanas listrik sampai cairan mendidih dan berwarna hijau jernih. Cairan dibiarkan sampai dingin, lalu dimasukkan ke dalam labu ukur $100 \mathrm{~mL}$ dan tambahkan akuades hingga tanda batas. Larutan dipipet $5 \mathrm{~mL}$ dimasukkan ke dalam alat destilasi, ditambahkan $5 \mathrm{~mL} \mathrm{NaOH} 30 \%$ dan beberapa tetes indikator pp dan didestilasi selama 10 menit. Hasil destilasi ditampung dalam erlenmeyer $125 \mathrm{~mL}$ yang berisi $10 \mathrm{~mL} \mathrm{H}_{3} \mathrm{BO}_{3} 2 \%$ dan indikator, lalu dititrasi dengan $\mathrm{HCl} 0,01 \mathrm{~N}$. Larutan blanko dianalisis seperti sampel [7][8].

\section{Hasil dan Pembahasan}

Dari penelitian yang sudah dilaksanakan didapatkan panjang gelombang maksiumum amilosa sebesar $645 \mathrm{~nm}$. Persamaan kurva kalibrasi pembanding amilosa didapatkan adalah Y=0,0246X + 0,0146 dengan nilai koefisien korelasi $(r)=0,9984$. Pembuatan kurva baku amilosa dilakukan untuk terpenuhinya hukum Lambert-Beer yaitu berupa garis lurus. Kriteria penerimaan dari koefisien korelasi adalah (r) $>0,99$ menunjukkan liniearitas yang sangat baik berarti bahwa hasil kurva antara absorban dan konsentrasi 
tersebut linear, yaitu apabila terjadi peningkatan pada nilai konsentrasi, nilai absorban juga meningkat. Kurva kalibrasi strandar amilosa dapat dilihat pada gambar 1.

Waktu operasional amilosa adalah 5 sampai 25 menit. Penghitungan waktu operasional dimulai pada saat penambahan pereaksi asam asetat $0,5 \mathrm{~N}$ dan iodium $2 \%$. Asam asetat berfungsi sebagai pemecah granula pati, sedangkan pereaksi iodium berfungsi menimbulkan warna pada larutan pati. Pembentukan warna antara iodium dengan amilum ini merupakan uji pembuktian adanya amilum. Tujuan penentuan waktu operasional adalah untuk mengetahui waktu pengukuran yang stabil dengan mengukur hubungan antara waktu pengukuran dengan absorbansi larutan. Semakin lama waktu pengukuran, maka ada kemungkinan senyawa yang berwarna tersebut menjadi rusak atau terurai sehingga intensitas warnanya turun akibatnya absorbansi juga turun. Karena alasan inilah, maka untuk pengukuran senyawa berwarna (hasil reaksi kimia) harus dilakukan pada saat waktu operasional [9].
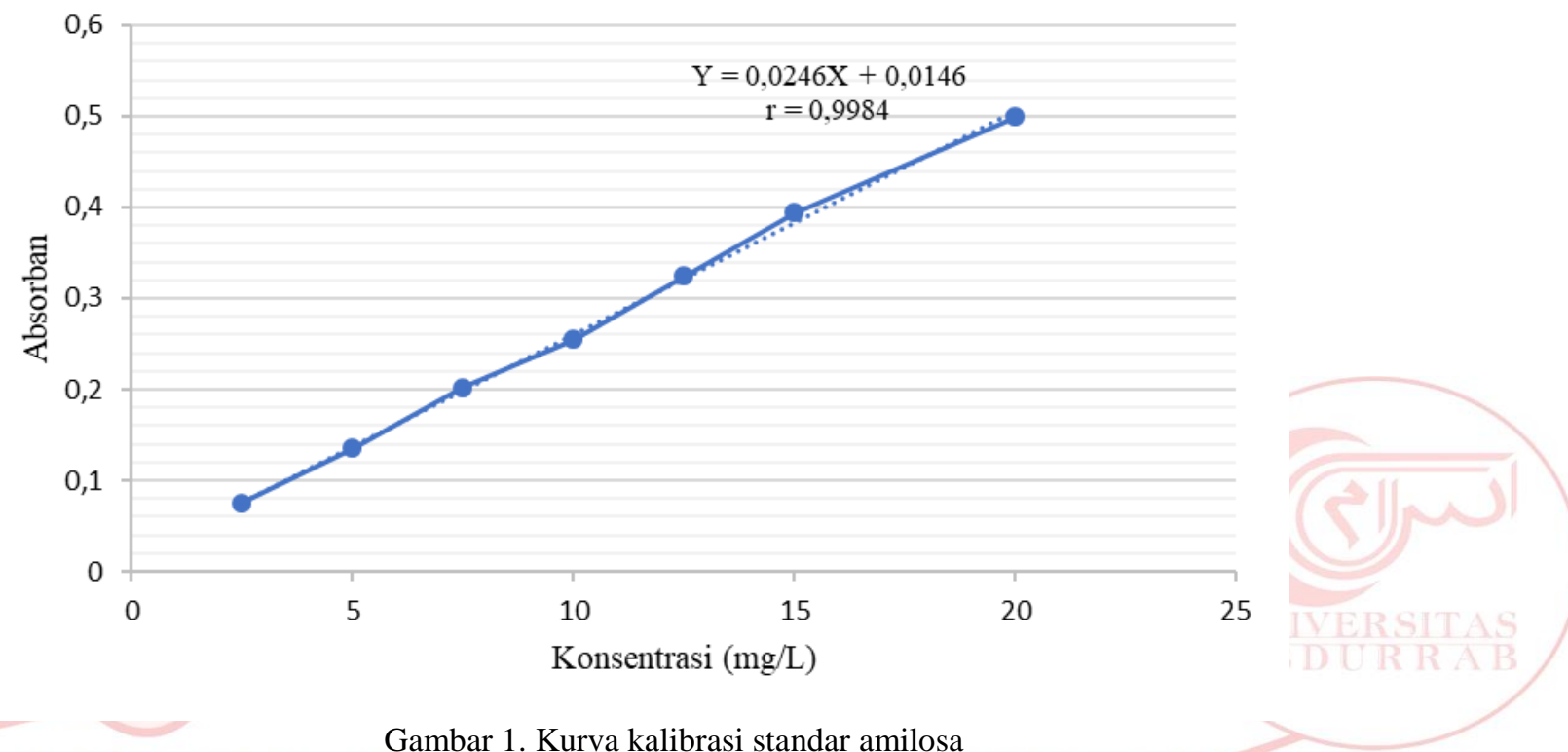

Gambar 1. Kurva kalibrasi standar amilosa

Kadar amilosa rata-rata pada beras Solok jenis anak daro organik adalah 28,90\% dan anak daro konvensional sebesar 28,04\%. Kadar amilosa rata-rata pada beras Solok jenis sokan organik adalah $30,32 \%$ dan sokan konvensional sebesar 30,94\%. Kadar amilosa pada sampel dengan lima kali pengulangan dapat dilihat pada Tabel I. Kadar amilosa menentukan rasa dan mutu nasi yang dihasilkan dan menentukan sifat fisik lainnya [10]. Berdasarkan kandungan amilosanya, beras (nasi) dapat dibagi menjadi empat golongan yaitu : (1) beras dengan kadar amilosa tinggi 25-33\%; (2) beras dengan kadar amilosa menengah 20-25\%; (3) beras dengan kadar amilosa rendah (9-20\%); dan (4) beras dengan kadar amilosa sangat rendah $(<9 \%)$ [11]. Beras dengan kadar amilosa tinggi mempunyai sifat nasi yang keras/pera, sedangkan beras dengan kadar amilosa rendah memiliki sifat nasi yang pulen [6]. Beras Solok jenis anak daro dan sokan termasuk dalam golongan beras dengan kadar amilosa tinggi. Beras yang memiliki kandungan amilosa tinggi memiliki Indeks Glikemik (IG) rendah. Beras dengan kadar amilosa tinggi akan lambat dicerna karena struktur amilosa yang kuat dan sulit tergelatinisasi, sehingga akan lambat menaikkan kadar gula darah dan memiliki IG yang rendah [12].

Kadar protein rata-rata pada beras Solok jenis anak daro organik adalah 8,79\% dan anak daro konvensional sebesar $8,15 \%$. Kadar protein rata-rata pada beras Solok jenis sokan organik adalah 8,50\% dan sokan konvensional sebesar 8,25\%. Penetapan kadar protein menggunakan metode semimikro kjeidhal. Senyawa nitrogen pada protein diubah menjadi ammonium sulfat oleh $\mathrm{H}_{2} \mathrm{SO}_{4}$ pekat. Ammonium sulfat yang terbentuk diuraikan dengan $\mathrm{NaOH}$. Ammoniak yang dibebaskan diikat dengan asam borat dan kemudian dititar dengan larutan baku asam klorida [8].

Untuk mengetahui apakah ada perbedaan yang signifikan terhadap rata-rata kadar amilosa beras anak daro dan sokan organik dan konvensional dilakukan uji T. Uji T digunakan untuk membandingkan apakah rata-rata dua kelompok yang diuji berbeda secara signifikan atau tidak [13]. Nilai $\mathrm{T}$ hitung dari masingmasing kelompok lebih kecil daripada nilai $\mathrm{T}$ tabel. Nilai $\mathrm{T}$ tabel pada $\mathrm{p} 0,95$ adalah 2,31 dan $\mathrm{T}$ tabel pada p 0,99 adalah 3,36. Apabila nilai T hitung < T tabel, artinya hasilnya tidak berbeda nyata. 
Tabel I. Kadar amilosa pada beras anak daro dan sokan

\begin{tabular}{|c|c|c|c|c|}
\hline No. & Sampel & Absorban & $\begin{array}{c}\text { Kadar Amilosa } \\
(\%)\end{array}$ & $\begin{array}{c}\text { Kadar Rata-Rata } \\
(\%)\end{array}$ \\
\hline \multirow[t]{5}{*}{1} & \multirow{5}{*}{$\begin{array}{l}\text { Beras Anak Daro } \\
\text { Organik }\end{array}$} & 0,362 & 28,21 & \multirow[t]{5}{*}{28,90} \\
\hline & & 0,389 & 30,38 & \\
\hline & & 0,372 & 29,06 & \\
\hline & & 0,342 & 26,62 & \\
\hline & & 0,387 & 30,25 & \\
\hline \multirow[t]{5}{*}{2} & \multirow{5}{*}{$\begin{array}{l}\text { Beras Anak Daro } \\
\text { Konvensional }\end{array}$} & 0,358 & 27,92 & \multirow[t]{5}{*}{28,04} \\
\hline & & 0,372 & 29,06 & \\
\hline & & 0,349 & 27,10 & \\
\hline & & 0,346 & 26,94 & \\
\hline & & 0,374 & 29,16 & \\
\hline \multirow[t]{5}{*}{3} & \multirow[t]{5}{*}{ Beras Sokan Organik } & 0,396 & 31,00 & \multirow[t]{5}{*}{30,32} \\
\hline & & 0,376 & 29,38 & \\
\hline & & 0,386 & 30,20 & \\
\hline & & 0,387 & 30,28 & \\
\hline & & 0,392 & 30,74 & \\
\hline \multirow[t]{5}{*}{4} & \multirow{5}{*}{$\begin{array}{l}\text { Beras Sokan } \\
\text { Konvensional }\end{array}$} & 0,405 & 31,71 & \multirow[t]{5}{*}{30,94} \\
\hline & & 0,413 & 32,50 & \\
\hline & & 0,387 & 30,24 & \\
\hline & & 0,382 & 29,93 & \\
\hline & & 0,387 & 30,28 & \\
\hline
\end{tabular}

\section{Kesimpulan}

Dari hasil penelitian ini dapat disimpulkan bahwa kadar amilosa beras Solok jenis anak daro organik adalah 28,90\%, anak daro konvensional 28,04\%, sokan organik 30,32\% dan sokan konvensional 30,94\%. Kadar protein beras Solok jenis anak daro organik 8,79\%, anak daro konvensional 8,15\%, sokan organik $8,50 \%$, dan sokan konvensional 8,25\%. Nilai T hitung dari masing-masing kelompok lebih kecil daripada nilai $\mathrm{T}$ tabel, dapat disimpulkan bahwa kadar amilosa dan protein pada beras anak daro dan sokan yang ditanam dengan sistem pertanian organik dan sistem pertanian konvensional hasilnya tidak berbeda nyata.

\section{REFERENSI}

[1] B. S. Nasional, "SNI 6729: 2013 Sistem Pertanian Organik,” Badan Standarisasi Nas., 2013.

[2] M. Purwasasmita and A. Sutaryat, Padi SRI Organik Indonesia. Bandung: Penebar Swadaya, 2014.

[3] S. Sriyanto, Panen Duit dari Bisnis Padi Organik. Jakarta: Agromedia Pustaka, 2010.

[4] H. J. D. Lalel, Z. Abidin, and L. Jutomo, "Sifat Fisiko Kimia Beras Merah Gogo Lokal Ende," J. Teknol. dan Ind. Pangan dan Ind. Pangan, vol. 20, no. 2, pp. 109-116, 2009.

[5] H. J. Chung, Q. Liu, L. Lee, and D. Wei, "Relationship between the structure, physicochemical properties and in vitro digestibility of rice starches with different amylose contents," Food Hydrocoll., vol. 25, no. 5, pp. 968-975, 2011.

[6] B. S. Nasional, "SNI 6128: 2008 Beras,” Badan Stand. Nas., 2008.

[7] R. Hasbullah and P. Riskia, "Pengaruh Lama Perendaman Terhadap Mutu Beras Pratanak pada Padi Varietas IR 64,” J. Keteknikan Pertan., vol. 27, no. 1, pp. 53-60, 2013.

[8] B. S. Nasional, "SNI 01-2891: 1992 Cara Uji Makanan dan Minuman," 1992.

[9] I. G. Gandjar and A. Rohman, Kimia Farmasi Analisis. Yogyakarta: Pustaka Pelajar, 2013.

[10] T. Muchtadi, Sugiyono, and F. A, Ilmu Pengetahuan Bahan Pangan. Bandung: Alfabeta, 2011.

[11] F. . Winarno, Kimia Pangan dan Gizi. Jakarta: Gramedia Pustaka Utama, 2004.

[12] R. Rimbawan, "Pengembangan Teknologi Pengolahan Beras Rendah Indeks Glikemik," J. Pangan, vol. 16, no. 1, pp. 70-75, 2007.

[13] A. Rohman, Statistika dan Kemometrika Dasar dalam Analisis Farmasi. Yogyakarta: Pustaka Pelajar, 2014. 